\title{
Sjögren's syndrome presenting with hypokalemic paralysis
}

\author{
Ben Ghezala Hassen, Snouda Salah, Ben Chiekh Imen, Ouali Jhen
}

\begin{abstract}
Introduction: Acute systemic weakness is a common reason for emergency department visit. Acute hypokalemic paralysis is one of its clinical presentation forms. It is a rare but treatable cause of acute weakness. We report a case that presented with hypokalemic paralysis in emergency room. Case Report: We report a rare case of a 36-year-old female presented with sudden onset flaccid left hemiparesis with no significant past clinical history. Initially the patient was considered as an ischemic stroke, but she was later found to have hypokalemia due to distal renal tubular acidosis and further diagnosed as case of Sjögren's syndrome. Conclusion: Acute flaccid neuromuscular weakness is a common presenting symptom in emergency room. Hypokalemia is an important differential diagnosis. The cause of hypokalemia should be sought. The diagnosis of distal renal tubular acidosis must be considered in patients presenting with hypokalemic paralysis and renal stones, and may be the first clue in the identification of an underlying autoimmune disorder, particularly Sjögren's syndrome.
\end{abstract}

Ben Ghezala Hassen', Snouda Salah², Ben Chiekh Imen², Ouali Jhen ${ }^{3}$

Affiliations: ${ }^{1}$ Medical Director Physician Director, Teaching Department of Emergency and Intensive Care Medicine, Zaghouan Hospital, Zaghouan, Tunisia; ${ }^{2}$ Medical Director, Teaching Department of Emergency and Intensive Care Medicine, Zaghouan Hospital, Zaghouan, Tunisia; ${ }^{4}$ Medical Director, Department of Nephrology, Zaghouan Hospital, Zaghouan, Tunisia.

Corresponding Author: Snouda Salah, Regional Hospital of Zaghouan, Avenue of Environment, Zaghouan 1100, Tunisia; Ph: +216 90269364; Fax: +216 72675772; Email: dr.snouda.rea@gmail.com

Received: 20 April 2015

Accepted: 10 May 2015

Published: 03 September 2015
Keywords: Hypokalemia paralysis, Neuromuscular weakness, Renal tubular acidosis, Sjögren's syndrome

\section{How to cite this article}

Hassen BG, Salah S, Imen BC, Jhen O. Sjögren's syndrome presenting with hypokalemic paralysis. Case Rep Int 2015;4:26-29.

Article ID: 100012CRINTBH2015

$* * * * * * * * *$

doi:10.5348/crint-2015-12-CR-7

\section{INTRODUCTION}

Acute systemic weakness is a common reason for emergency department visit. The etiologies of this syndrome are very diverse including neurologic, metabolic, and infectious causes. Among its clinical presentation forms, we find the acute hypokalemic paralysis, which characterized by acute systemic weakness and low serum potassium. It is a rare but treatable cause of acute weakness. However, treatment modalities will differ in each of the above-described etiologies and it requires careful evaluation of patient to reach the final diagnosis. We report a case that presented with hypokalemic paralysis in emergency room. Initially the patient was considered as an ischemic stroke, but by step-wise approach, we finally reached the diagnosis.

\section{CASE REPORT}

A 36-year-old female was admitted in emergency room with sudden onset left hemiparesis. She has a history of recurrent urinary tract infections with left 
nephrectomy for renal stones and pyonephrosis, polyuricpolydipsic syndrome for eight years with normal blood sugar level and hypertension.

The patient did not have history of nausea, vomiting, diarrhea or use of any drugs. Her family history was insignificant. On examination, she was afebrile, pulse was $86 / \mathrm{min}$, regular, blood pressure $130 / 80 \mathrm{mmHg}$, Patient looked pale and dehydrated. Cardiac examination was normal. Examination of lungs and abdomen were also normal. Neurological examination revealed flaccid muscle weakness involving all four limbs primarily in the left side with areflexia without sensory involvement. Plantar reflexes were flexor bilaterally.

The electrocardiogram has shown flattened $\mathrm{T}$ waves, ST depression and presence of subtle $U$ waves (Figure 1). Laboratory results are summarized in Table 1. HBsAg, HCV RNA, HIV were negative.

The diagnosis of ischemic stroke was suspected in a history of hypertension and sudden onset. A brain scan was normal, which is not against the diagnosis. However, renal tubular acidosis (RTA) was suspected in the presence of hyperchloremic metabolic acidosis, a

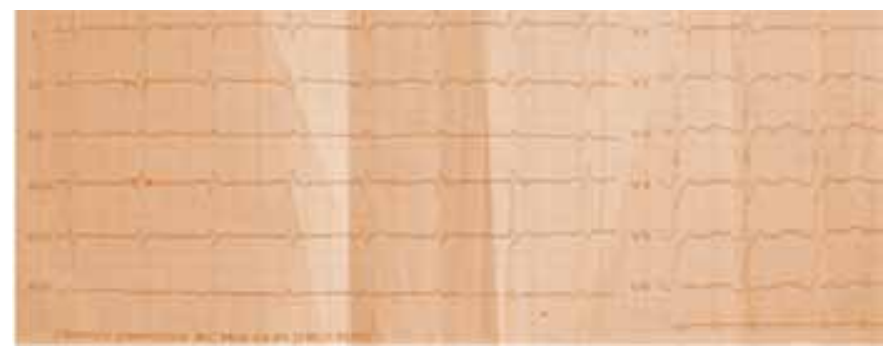

Figure 1: Electrocardiogram changes in the patient. urine $\mathrm{pH}$ greater than 7 and negative urine culture after 48 hours with no history of digestive disorders or diuretic usage. Autoantibody screen revealed positive antinuclear antibody (640), anti-SSA and anti-RO52 antibodies. Anti dsDNA, anti-Sm, anti-SSB, anti-SCL70 and anti-JO1 antibodies, rheumatoid factor and CIC were negative. These reports and distal RTA raised a high index of suspicion of Sjögren's syndrome.

To confirm the diagnosis, a labial biopsy was performed showing a lymphoplasmacytic infiltrate of grade IV according to Chisholm's classification, which is in favor of Sjögren's syndrome.

Patient received a potassium supplementation at the dose of $1 \mathrm{~g}$ per hour and alkalinization by sodium bicarbonate at the dose of $100 \mathrm{mEq}$ in the emergency department. She was treated by prednisolone at the dose of $0.5 \mathrm{mg} / \mathrm{kg} /$ day for six weeks with good outcome. She has a regular nephrology follow-up.

\section{DISCUSSION}

Distal RTA is a condition characterized by an inability of the distal nephron to acidify the urine. It is characterized by hyperchloremic hypokalemic, metabolic acidosis with a normal serum anion gap and urine $\mathrm{pH}$ greater than $5.5[1]$.

Distal RTA is rare and it may be primary or secondary resulting from various disorders like autoimmune diseases, kidney transplantation, nephrocalcinosis, medullary sponge kidney, chronic obstructive uropathy, drugs (mainly amphotericin B, ifosfamide, and lithium).

Table 1: Laboratory findings of the patient

\begin{tabular}{|c|c|c|c|c|c|}
\hline Serum Sodium & $146 \mathrm{mEq} / \mathrm{l}$ & $138-142$ & Serum Lactate & $1.8 \mathrm{mmol} / \mathrm{l}$ & $<2$ \\
\hline Serum Potassium & $1.16 \mathrm{mEq} / \mathrm{l}$ & $3 \cdot 5^{-5}$ & Serum Protein & $74 \mathrm{~g} / \mathrm{l}$ & 60 \\
\hline Serum Chlorine & $122 \mathrm{mEq} / \mathrm{l}$ & 100 & Urine Sodium & $180 \mathrm{mmol} / 24 \mathrm{~h}$ & $>40 / 24 \mathrm{~h}$ \\
\hline Serum Calcium & $1.9 \mathrm{mmol} / \mathrm{l}$ & 2.2 & Urine Potassium & $55 \mathrm{mmol} / 24 \mathrm{~h}$ & $>20 / 24 \mathrm{~h}$ \\
\hline Serum Phosphorus & $0.45 \mathrm{mmol} / \mathrm{l}$ & 0.8 & Urine Chlorine & $6.1 \mathrm{mmol} / 24 \mathrm{~h}$ & $>20 / 24 \mathrm{~h}$ \\
\hline Serum Urea & $5.36 \mathrm{mmol} / \mathrm{l}$ & $<7.5$ & Urine $\mathrm{pH}$ & 7 & $4 \cdot 6-8$ \\
\hline Creatinine & $86 \mu \mathrm{mol} / \mathrm{l}$ & $<100$ & Urine Protein & Trace & o \\
\hline ASAT & $8.9 \mathrm{IU} / 1$ & 40 & Hematuria & Trace & 0 \\
\hline ALAT & $6.3 \mathrm{IU} / 1$ & 40 & Serum anion gap & $12 \mathrm{mEq} / \mathrm{l}$ & $12-16$ \\
\hline TBil/C & $4 / 1 \mathrm{mg} / \mathrm{dl}$ & $<5$ & Urine anion gap & $22 \mathrm{mEq} / \mathrm{l}$ & -10 to 10 \\
\hline C-reactive Protein & $2.13 \mathrm{mg} / \mathrm{l}$ & $<4$ & Urine culture & Negative & Negative \\
\hline Serum $\mathrm{pH}$ & 7.26 & $7 \cdot 38-7.42$ & Hemoglobin & $12.8 \mathrm{mg} / \mathrm{dl}$ & $12-16$ \\
\hline $\mathrm{PaO}_{2}$ & $77.7 \mathrm{mmHg}$ & 100 & WBC & $15.4 \times 10^{9} / \mathrm{L}$ & $4-9 \times 10^{9} / \mathrm{L}$ \\
\hline $\mathrm{PaCO} 2$ & $25.9 \mathrm{mmHg}$ & $38-42$ & $\mathrm{RBC}$ & $5.1 \times 10^{12} / \mathrm{L}$ & $4.7-6.1 \times 10^{12} / \mathrm{L}$ \\
\hline $\mathrm{HCO}_{3-}^{-}$ & $11.9 \mathrm{mmHg}$ & $22-26$ & Platelet Count & $243 \times 10^{9} / \mathrm{L}$ & $150-400 \times 10^{9} / \mathrm{L}$ \\
\hline $\mathrm{SaO}_{2}$ & $93.7 \%$ & 100 & INR & 1.1 & $0.9-1.2$ \\
\hline
\end{tabular}


Among the autoimmune diseases that may be associated with this syndrome, we find the Sjögren's syndrome in which, the clinical presentation can be associated with distal acidification in up to $25 \%$ of patients, a mild metabolic acidosis and in some case, hypokalemic paralysis can be its presenting symptom [2, 3]. The mechanism by which Sjögren's syndrome leads to distal RTA is incompletely understood. It may be due to high levels of anti-carbonic anhydrase anti-bodies, which affect the function of carbonic anhydrase in cortical collecting ducts [4] or a lack of intact H+ ATPase pumps in the intercalated cells [5]. Usually, patients with distal RTA present with symptoms of nephrolithiasis, but the symptoms of hypokalemia and hypocalcaemia may be the first abnormalities, like in our case. The clinical manifestations of potassium depletion vary between individual patients, and their severity depends on the degree of hypokalemia. It can range from fatigue, myalgia and muscular weakness to complete paralysis. Correction of hypokalemia and alkaline replacement are the standard therapy of distal RTA. Hypokalemia should be corrected first because alkaline replacement can aggravate hypokalemia resulting in dangerous consequences. Steroid therapy should be considered in presence of severe RTA and hypokalemic paralysis in Sjögren's syndrome to prevent relapses and to improve the response to replacement therapy $[6,7-11]$.

\section{CONCLUSION}

Acute flaccid neuromuscular weakness is a common presenting symptom in emergency room. Hypokalemia is an important differential diagnosis besides primary neuromuscular diseases. The cause of hypokalemia should be sought. The diagnosis of distal renal tubular acidosis must be considered in patients presenting with hypokalemic paralysis and renal stones, and may be the first clue in the identification of an underlying autoimmune disorder, particularly Sjögren's syndrome.

$* * * * * * * * *$

\section{Author Contributions}

Ben Ghezala Hassen - Substantial contributions to conception and design, Acquisition of data, Analysis and interpretation of data, Drafting the article, Critical revision of the article, Final approval of the version to be published

Snouda Salah - Substantial contributions to conception and design, Acquisition of data, Analysis and interpretation of data, Drafting the article, Critical revision of the article, Final approval of the version to be published

Ouali Jihen - Substantial contributions to conception and design, Acquisition of data, Analysis and interpretation of data, Drafting the article, Critical revision of the article, Final approval of the version to be published
Ben chiekh Imen - Substantial contributions to conception and design, Acquisition of data, Analysis and interpretation of data, Drafting the article, Critical revision of the article, Final approval of the version to be published

\section{Guarantor}

The corresponding author is the guarantor of submission.

\section{Conflict of Interest}

Authors declare no conflict of interest.

\section{Copyright}

(C) 2015 Ben Ghezala Hassen et al. This article is distributed under the terms of Creative Commons Attribution License which permits unrestricted use, distribution and reproduction in any medium provided the original author(s) and original publisher are properly credited. Please see the copyright policy on the journal website for more information.

\section{REFERENCES}

1. Asplin JR, Coe FL. Tubular disorders. In: Kasper DL, Braunwald E, Fauci AS, eds. Harrison's Principle of Internal Medicine. 16th ed. U.S.A. The McGraw-Hill Companies, Inc; 2005;1698-9.

2. Chen LH, Hsu PN, Chen MY, Lee KL, Hsieh SC, Yu CL. Renal tubular acidosis in patients with primary Sjögren's syndrome. J Rheumatol 2007;21:13-9.

3. Poux JM, Peyronnet P, Le Meur Y, Favereau JP, Charmes JP, Hypokalemic quadriplegia and respiratory arrest revealing primary Sjögren's syndrome. Clin Nephrol 1992 Apr;37(4):189-91.

4. Takemoto F, Hoshino J, Sawa N, et.al. Autoantibodies against carbonic anhydrase II are increased in renal tubular acidosis associated with Sjogren syndrome. Am J Med 2005 Feb;118(2):181-4.

5. Joo KW, Jeon US, Han JS, et.al. Absence of H(+)ATPase in the intercalated cells of renal tissues in classic distal renal tubular acidosis. Clin Nephrol 1998 Apr;49(4):226-31.

6. Siamopoulos KC, Mavridis AK, Elisaf M, Drosos AA, Moutsopoulos HM. Kidney involvement in primary Sjögren's syndrome. Scand J Rheumatol Suppl 1986;61:156-6o.

7. Soy M, Pamuk ON, Gerenli M, Celik Y. A primary Sjögren's syndrome patient with distal renal tubular acidosis, who presented with symptoms of hypokalemic periodic paralysis: Report of a case study and review of the literature. Rheumatol Int 2005 Nov;26(1):86-9.

8. al-Jubouri MA, Jones S, Macmillan R, Harris C, Griffiths RD. Hypokalaemic paralysis revealing Sjögren syndrome in an elderly man. J Clin Pathol 1999 Feb;52(2):157-8.

9. Logan JL, Ahmed J. Critical hypokalemic renal tubular acidosis due to Sjögren's syndrome: association with the purported immune stimulant echinacea. Clin Rheumatol 2003 May;22(2):158-9. 
quadriparesis as the presenting manifestation of Gougerot-Sjögren's syndrome.

[Article in French] Rev Med Interne 2011 Oct;32(10):e108-10.
Access full text article on other devices

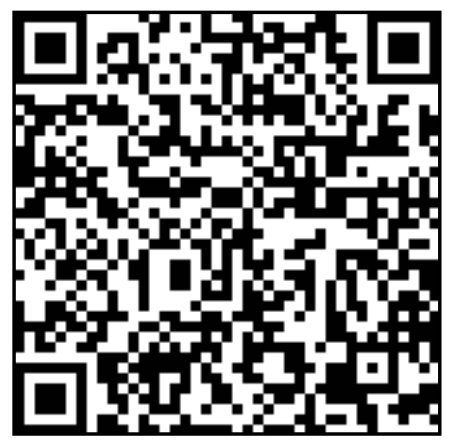

Access PDF of article on other devices

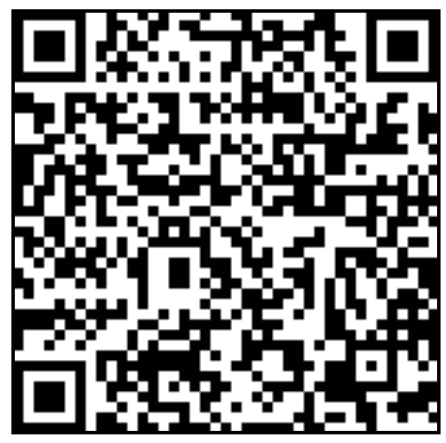

